\title{
The 100 most influential manuscripts in andrology: a bibliometric analysis
}

\author{
Nicholas Bullock ${ }^{1 *}$ (D, Thomas Ellul ${ }^{2}$, Adam Bennett ${ }^{2}$, Martin Steggall ${ }^{2,3}$ and Gareth Brown ${ }^{2,3}$
}

\begin{abstract}
Background: As the specialty of Andrology expands it is important to establish the most important studies that have shaped, and continue to shape, current research and clinical practice. Bibliometric analysis involving a citation rank list is an established means by which to identify the published material within a given field that has greatest intellectual influence. This bibliometric analysis sought to identify the 100 most influential manuscripts in Andrology, as well as the key research themes that have shaped contemporary understanding and management of andrological conditions.

Methods: The Thompson Reuters Web of Science citation indexing database was interrogated using a number of search terms chosen to reflect the full spectrum of andrological practice. Results were ranked according to citation number and further analysed according to subject, first and senior author, journal, year of publication, institution and country of origin.

Results: The Web of Science search returned a total of 24,128 manuscripts. Citation number of the top 100 articles ranged from 2819 to 218 (median 320). The most cited manuscript (by Feldman et al., The Journal of Urology 1994; 2819 citations) reported the prevalence and risk factors for erectile dysfunction (ED) in the Massachusetts Male Ageing Study. The Journal of Urology published the highest number of manuscripts $(n=11)$, followed by the New England Journal of Medicine $(n=10)$. The most common theme represented within the top 100 manuscripts was erectile dysfunction ( $n=46)$, followed jointly by hypogonadism and male factor infertility ( $n=24$ respectively).

Conclusion: Erectile dysfunction should be considered the most widely researched, published and cited field within andrological practice. This study provides a list of the most influential manuscripts in andrology and serves as a reference of what comprises a 'highly citable' paper for both researchers and clinicians.
\end{abstract}

Keywords: Andrology, Influential, Citation rank, Bibliometric analysis

\footnotetext{
*Correspondence: bullocknp@cardiff.ac.uk

'Division of Cancer and Genetics, Cardiff University School of Medicine,

Heath Park, Cardiff CF14 4XN, UK

Full list of author information is available at the end of the article
}

(c) The Author(s). 2018 Open Access This article is distributed under the terms of the Creative Commons Attribution 4.0 International License (http://creativecommons.org/licenses/by/4.0/), which permits unrestricted use, distribution, and reproduction in any medium, provided you give appropriate credit to the original author(s) and the source, provide a link to the Creative Commons license, and indicate if changes were made. The Creative Commons Public Domain Dedication waiver (http://creativecommons.org/publicdomain/zero/1.0/) applies to the data made available in this article, unless otherwise stated. 


\section{Résumé}

Contexte: Etant donné que la spécialité Andrologie se développe, il est important de dresser un inventaire des études les plus importantes qui ont façonné, et qui continuent à façonner, la recherche actuelle et la pratique clinique. L'analyse bibliométrique, qui inclue une liste de rang de citations, est un moyen bien établi pour identifier le matériel publié, dans un champ donné, qui a la plus grande influence intellectuelle. La présente analyse bibliométrique cherche à identifier les 100 manuscrits les plus influents en Andrologie, ainsi que les principaux thèmes de recherche qui ont façonné la compréhension et la prise en charge contemporaines des situations andrologiques.

Méthodes: La base de données d'indexation des citations du Web of Science de Thompson Reuters a été interrogée en utilisant un nombre de termes de recherche choisis pour refléter l'éventail complet de la pratique andrologique. Les résultats ont été classés selon leur nombre de citations, puis ensuite analysés en fonction du sujet, des premier et dernier auteurs, du journal, de l'année de publication, de l'institution et du pays d'origine.

Résultats: La recherche sur le Web of Science a rapporté un total de 24128 manuscrits. Le nombre de citations des 100 premiers articles va de 2819 à 218 (médiane 320). L'article le plus cité (de Feldman et al., The Journal of Urology 1994 ; 2819 citations) rapportait la prévalence et les facteurs de risque de la dysfonction érectile (DE) dans l'étude du Massachusetts menée chez l'homme vieillissant. The Journal of Urology a publié le plus grand nombre de manuscrits ( $n=11$ ), suivi du New England Journal of Medicine $(n=10)$. Le thème le plus souvent représenté dans les manuscrits du top 100 était la dysfonction érectile $(n=46)$, suivi conjointement par l'hypogonadisme et l'infertilité d'origine masculine (respectivement $\mathrm{n}=24$ ).

Conclusion: La dysfonction érectile devrait être considérée comme le champ de la pratique andrologique qui a le plus largement fait l'objet de recherches, de publications et de citations. La présente étude fournit une liste des manuscrits les plus influents en andrologie, et constitue une référence sur ce que signifie un article 'fortement cité' à la fois pour les chercheurs et pour les cliniciens.

\section{Background}

Andrology is the medical specialty that focuses on many aspects of male health, comprising a wide range of conditions of the male reproductive system, as well as urological pathologies that are specific to men. Although the clinical science had been studied for many years, it was not until after the introduction of the term 'andrology' in 1951 that scientists and clinicians from a diverse range of backgrounds began to refer to themselves as 'andrologists' [1]. Since then the discipline has continued to evolve, with the introduction of national and international societies, recognised and accredited training courses and a number of high quality dedicated journals. In the present day, andrologists are involved in the management of a wide spectrum of diseases ranging from male factor infertility through to hypogonadism and penile cancer. As the specialty grows and the body of literature focusing on andrological topics expands it is important to establish the most important and influential manuscripts that have shaped, and continue to shape, current research and clinical practice.

The generation of a citation rank list is one method of identifying the published material within a given field that has greatest intellectual influence [2]. A citation refers to the referencing of an article by another peer-reviewed publication. It is therefore probable that articles which have the greatest impact on the scientific and clinical communities are cited many times more than those which have had little impact. Citation analysis is the process of ranking the most frequently cited articles in order to produce a citation rank list. In addition, citation numbers can be used to rank journals through calculation of their 'impact factor.' This is a measure of the average number of citations a manuscript published in a particular journal received during a specific timeframe and is often used a surrogate marker for journal quality.

A number of clinical disciplines have employed citation analysis to determine the most influential articles in their field. These include entire specialties such as general surgery [3], plastic surgery [4] and orthopaedic surgery [5], as well as subspecialties such as laparoscopic and emergency abdominal surgery [6, 7]. Whilst citation analysis has been conducted within urology as a whole $[8,9]$, and more specifically for male factor infertility [10], no study to date has been undertaken to determine the most influential manuscripts in andrology. This bibliometric analysis therefore aimed to identify the most influential articles in the field, as well as key research themes that have been instrumental in developing our contemporary understanding and management of andrological conditions.

\section{Methods}

The Thompson Reuters Web of Science citation indexing database was interrogated using the method 
Table 1 The 100 most cited manuscripts in Andrology

\begin{tabular}{|c|c|c|}
\hline Rank & Manuscript (first author, title, journal and year) & Citations \\
\hline 1 & $\begin{array}{l}\text { Feldman HA. Impotence and its medical and psychosocial correlates - results of the Massachusetts male aging } \\
\text { study. Journal of Urology } 1994 .\end{array}$ & 2819 \\
\hline 2 & $\begin{array}{l}\text { Rosen RC. The international index of erectile function (IIEF): A multidimensional scale for assessment of erectile } \\
\text { dysfunction. Urology } 1997 .\end{array}$ & 2480 \\
\hline 3 & Goldstein I. Oral sildenafil in the treatment of erectile dysfunction. New England Journal of Medicine 1998. & 1515 \\
\hline 4 & $\begin{array}{l}\text { Rosen RC. Development and evaluation of an abridged, 5-item version of the International Index of Erectile Func- } \\
\text { tion (IIEF-5) as a diagnostic tool for erectile dysfunction. International Journal of Impotence Research } 1999 .\end{array}$ & 1325 \\
\hline 5 & $\begin{array}{l}\text { Droller MJ. Impotence: NIH consensus development panel on impotence. Journal of the American Medical } \\
\text { Association } 1993 .\end{array}$ & 1270 \\
\hline 6 & $\begin{array}{l}\text { de Roux N. Hypogonadotropic hypogonadism due to loss of function of the KiSS1-derived peptide receptor } \\
\text { GPR54. Proceedings of the National Academy of Sciences of the United States of America } 2003 .\end{array}$ & 1237 \\
\hline 7 & $\begin{array}{l}\text { Walsh PC. Impotence following radical prostatectomy - insight into etiology and prevention. Journal of Urology } \\
1982 .\end{array}$ & 1044 \\
\hline 8 & Lue TF. Drug therapy: Erectile dysfunction. New England Journal of Medicine 2000. & 793 \\
\hline 9 & $\begin{array}{l}\text { Rosen R. Lower urinary tract symptoms and male sexual dysfunction: The multinational survey of the aging male } \\
\text { (MSAM-7). European Urology } 2003 .\end{array}$ & 675 \\
\hline 10 & $\begin{array}{l}\text { Evenson DP. Sperm chromatin structure assay: Its clinical use for detecting sperm DNA fragmentation in male } \\
\text { infertility and comparisons with other techniques. Journal of Andrology } 2002 .\end{array}$ & 610 \\
\hline 11 & $\begin{array}{l}\text { Eddy EM. Targeted disruption of the estrogen receptor gene in male mice causes alteration of spermatogenesis } \\
\text { and infertility. Endocrinology } 1996 .\end{array}$ & 607 \\
\hline 12 & $\begin{array}{l}\text { Johannes CB. Incidence of erectile dysfunction in men } 40 \text { to } 69 \text { years old: Longitudinal results from the } \\
\text { Massachusetts male aging study. Journal of Urology } 2000 \text {. }\end{array}$ & 558 \\
\hline 13 & $\begin{array}{l}\text { Aytac IA. The likely worldwide increase in erectile dysfunction between } 1995 \text { and } 2025 \text { and some possible policy } \\
\text { consequences. British Journal of Urology International } 1999 .\end{array}$ & 553 \\
\hline 14 & $\begin{array}{l}\text { Muscatelli F. Mutations in the dax-1 gene give rise to both } x \text {-linked adrenal hypoplasia congenita and hypogona- } \\
\text { dotropic hypogonadism. Nature } 1994 .\end{array}$ & 536 \\
\hline 15 & $\begin{array}{l}\text { Wu FCW. Identification of Late-Onset Hypogonadism in Middle-Aged and Elderly Men. New England Journal of } \\
\text { Medicine } 2010 .\end{array}$ & 524 \\
\hline 16 & $\begin{array}{l}\text { Katznelson L. Increase in bone density and lean body mass during testosterone administration in men with } \\
\text { acquired hypogonadism. Journal of Clinical Endocrinology \& Metabolism } 1996 .\end{array}$ & 516 \\
\hline 17 & Sharma RK. Role of reactive oxygen species in male infertility. Urology 1996. & 516 \\
\hline 18 & $\begin{array}{l}\text { Braun M. Epidemiology of erectile dysfunction: results of the 'Cologne Male Survey'. International Journal of } \\
\text { Impotence Research } 2000 .\end{array}$ & 511 \\
\hline 19 & $\begin{array}{l}\text { Mason AJ. A deletion truncating the gonadotropin-releasing-hormone gene is responsible for hypogonadism in } \\
\text { the hpg mouse. Science } 1986 .\end{array}$ & 492 \\
\hline 20 & Krane RJ. Impotence. New England Journal of Medicine 1989. & 482 \\
\hline 21 & $\begin{array}{l}\text { Thompson IM. Erectile dysfunction and subsequent cardiovascular disease. Journal of the American Medical } \\
\text { Association } 2005 .\end{array}$ & 481 \\
\hline 22 & Tremellen K. Oxidative stress and male infertility-a clinical perspective. Human Reproduction Update 2008. & 479 \\
\hline 23 & Lue TF. Physiology of erection and pharmacological management of impotence. Journal of Urology 1987. & 458 \\
\hline 24 & Cattanach BM. Gonadotrophin-releasing hormone deficiency in a mutant mouse with hypogonadism. Nature 1977. & 453 \\
\hline 25 & $\begin{array}{l}\text { de Tejada IS. Impaired neurogenic and endothelium-mediated relaxation of penile smooth-muscle from diabetic } \\
\text { men with impotence. New England Journal of Medicine } 1989 .\end{array}$ & 438 \\
\hline 26 & $\begin{array}{l}\text { Esposito K. Effect of lifestyle changes on erectile dysfunction in obese men - A randomized controlled trial. Journal } \\
\text { of the American Medical Association } 2004 .\end{array}$ & 434 \\
\hline 27 & $\begin{array}{l}\text { Feldman HA. Erectile dysfunction and coronary risk factors: Prospective results from the Massachusetts Male Aging } \\
\text { Study. Preventive Medicine } 2000 .\end{array}$ & 431 \\
\hline 28 & Boolell M. Sildenafil, a novel effective oral therapy for male erectile dysfunction. British Journal of Urology 1996. & 423 \\
\hline 29 & $\begin{array}{l}\text { Terrett NK. Sildenafil (VIAGRA), a potent and selective inhibitor of type } 5 \text { cGMP phosphodiesterase with utility for } \\
\text { the treatment of male erectile dysfunction. Bioorganic \& Medicinal Chemistry Letters } 1996 .\end{array}$ & 421 \\
\hline 30 & Thorner MO. Long-term treatment of galactorrhea and hypogonadism with bromocriptine. British Medical Journal & 421 \\
\hline
\end{tabular}


Table 1 The 100 most cited manuscripts in Andrology (Continued)

\begin{tabular}{lll}
\hline Rank & Manuscript (first author, title, journal and year) & Citations \\
\hline 31 & Hatzimouratidis K. Guidelines on Male Sexual Dysfunction: Erectile Dysfunction and Premature Ejaculation. & 420 \\
32 & European Urology 2010. & 418 \\
33 & Dubin L. Etiologic factors in 1294 consecutive cases of male infertility. Fertility and Sterility 1971. & 417 \\
34 & Rendell MS. Sildenafil for treatment of erectile dysfunction in men with diabetes - A randomized controlled trial. \\
& Journal of the American Medical Association 1999. \\
35 & Tut TG. Long polyglutamine tracts in the androgen receptor are associated with reduced trans-activation, impaired \\
36 & Sperm production, and male infertility. Journal of Clinical Endocrinology \& Metabolism 1997. \\
37 & Carter JN. Prolactin-secreting tumors and hypogonadism in 22 men. New England Journal of Medicine 1978.
\end{tabular}

38 Dix DJ. Targeted gene disruption of Hsp70-2 results in failed meiosis, germ cell apoptosis, and male infertility. Proceedings of the National Academy of Sciences of the United States of America 1996. Update 2003. Journal of Psychiatry 1983. of Medicine 1997. Journal of Impotence Research 1998. from the Massachusetts Male Aging Study. Psychosomatic Medicine 1998.

Montorsi F. Erectile dysfunction prevalence, time of onset and association with risk factors in 300 consecutive patients with acute chest pain and angiographically documented coronary artery disease. European Urology 2003.

Mulligan T. Prevalence of hypogonadism in males aged at least 45 years: the HIM study. International Journal of Clinical Practice 2006.

Brock GB. Efficacy and safety of tadalafil for the treatment of erectile dysfunction: Results of integrated analyses. Journal of Urology 2002. males and patients with hypogonadotropic and hypergonadotropic hypogonadism. Journal of Clinical Endocrinology \& Metabolism 1972. potence. Journal of Urology 1985. mone receptor. New England Journal of Medicine 1997. Medicine 1996.

$57 \quad$ Agarwal A. Clinical relevance of oxidative stress in male factor infertility: An update. American Journal of Reproductive Immunology 2008. 
Table 1 The 100 most cited manuscripts in Andrology (Continued)

\begin{tabular}{lll}
\hline Rank & Manuscript (first author, title, journal and year) & Citations \\
\hline 60 & Finkelstein JS. Osteoporosis in men with idiopathic hypogonadotropic hypogonadism. Annals of Internal Medicine \\
& 1987. & \\
61 & Kodama H. Increased oxidative deoxyribonucleic acid damage in the spermatozoa of infertile male patients.
\end{tabular}

62 Lapatto R. Kiss1(-/-) mice exhibit more variable hypogonadism than Gpr54(-/-) mice. Endocrinology 2007.

63 Smith JC. The effects of induced hypogonadism on arterial stiffness, body composition, and metabolic parameters in males with prostate cancer. Journal of Clinical Endocrinology \& Metabolism 2001.

64 McCulloch DK. The prevalence of diabetic impotence. Diabetologia 1980.

Debraekeleer M. Cytogenetic studies in male-infertility - a review. Human Reproduction 1991.

Selvin E. Prevalence and risk factors for erectile dysfunction in the US. American Journal of Medicine 2007.

Mulryan K. Reduced vas deferens contraction and male infertility in mice lacking P2X(1) receptors. Nature 2000.

Solomon $\mathrm{H}$. Erectile dysfunction and the cardiovascular patient: endothelial dysfunction is the common denominator. Heart 2003.

Hendren SK. Prevalence of male and female sexual dysfunction is high following surgery for rectal cancer. Annals of Surgery 2005.

Finkelstein JS. Increases in bone-density during treatment of men with idiopathic hypogonadotropic hypogonadism. Journal of Clinical Endocrinology \& Metabolism 1989.

Chang CS. Infertility with defective spermatogenesis and hypotestosteronemia in male mice lacking the androgen receptor in Sertoli cells. Proceedings of the National Academy of Sciences of the United States of America 2004.

Wang C. Investigation, treatment and monitoring of late-onset hypogonadism in males. European Journal of Endocrinology 2008.

Weiss J. Hypogonadism caused by a single amino-acid substitution in the beta subunit of luteinizing-hormone. New England Journal of Medicine 1992.

Kaiser DR. Impaired brachial artery endothelium-dependent and -independent vasodilation in men with erectile dysfunction and no other clinical cardiovascular disease. Journal of the American College of Cardiology 2004.

Ellenber M. Impotence in diabetes - neurologic factor. Annals of Internal Medicine 1971.

Althof SE. EDITS: Development of questionnaires for evaluating satisfaction with treatments for erectile dysfunction. Urology 1999.

Kapoor D. Clinical and biochemical assessment of hypogonadism in men with type 2 diabetes: Correlations with bioavailable testosterone and visceral adiposity. Diabetes Care 2007.

79 Maden C. History of circumcision, medical conditions, and sexual-activity and risk of penile cancer. Journal of the National Cancer Institute 1993.

Palermo GD. Intracytoplasmic sperm injection - a novel treatment for all forms of male factor infertility. Fertility and Sterility 1995. Metabolism 1985. lates of erectile dysfunction. Urology 2003. 
Table 1 The 100 most cited manuscripts in Andrology (Continued)

\begin{tabular}{|c|c|c|}
\hline Rank & Manuscript (first author, title, journal and year) & Citations \\
\hline 89 & $\begin{array}{l}\text { User HM. Penile weight and cell subtype specific changes in a post-radical prostatectomy model of erectile dys- } \\
\text { function. Journal of Urology } 2003 .\end{array}$ & 233 \\
\hline 90 & $\begin{array}{l}\text { Seminara SB. Gonadotropin-releasing hormone deficiency in the human Idiopathic hypogonadotropic hypogonad- } \\
\text { ism and Kallmann's syndrome: Pathophysiological and genetic considerations. Endocrine Reviews } 1998 .\end{array}$ & 233 \\
\hline 91 & $\begin{array}{l}\text { Korenman SG. Secondary hypogonadism in older men - its relation to impotence. Journal of Clinical } \\
\text { Endocrinology \& Metabolism } 1990 .\end{array}$ & 231 \\
\hline 92 & $\begin{array}{l}\text { Talcott JA. Patient-reported impotence and incontinence after nerve-sparing radical prostatectomy. Journal of the } \\
\text { National Cancer Institute } 1997 .\end{array}$ & 229 \\
\hline 93 & $\begin{array}{l}\text { Montague DK. American Urological Association guideline on the management of priapism. Journal of Urology } \\
2003 .\end{array}$ & 228 \\
\hline 94 & $\begin{array}{l}\text { Marks LS. Effect of testosterone replacement therapy on prostate tissue in men with late-onset hypogonadism - A } \\
\text { randomized controlled trial. Journal of the American Medical Association } 2006 .\end{array}$ & 226 \\
\hline 95 & Benet AE. The epidemiology of erectile dysfunction. Urologic Clinics of North America 1995. & 225 \\
\hline 96 & Sikka SC. Role of oxidative stress and antioxidants in male infertility. Journal of Andrology 1995. & 225 \\
\hline 97 & Balhorn R. Aberrant protamine-1 protamine-2 ratios in sperm of infertile human males. Experientia 1988. & 225 \\
\hline 98 & $\begin{array}{l}\text { Daling JR. Penile cancer: importance of circumcision, human papillomavirus and smoking in in situ and invasive } \\
\text { disease. International Journal of Cancer } 2005 .\end{array}$ & 224 \\
\hline 99 & $\begin{array}{l}\text { Cummins JM. Molecular-biology of human male-infertility - links with aging, mitochondrial genetics, and oxidative } \\
\text { stress. Molecular Reproduction and Development } 1994 .\end{array}$ & 224 \\
\hline 100 & $\begin{array}{l}\text { Saleh RA. Negative effects of increased sperm DNA damage in relation to seminal oxidative stress in men with } \\
\text { idiopathic and male factor infertility. Fertility and Sterility } 2003 .\end{array}$ & 218 \\
\hline
\end{tabular}

previously described by Ellul et al. [6]. As andrology is a broad subspecialty that draws from a range of other disciplines, it is probable that influential articles pertaining to relevant topics have been published in a wide array of journals, not just those specific to urology and sexual medicine. A number of title search terms were therefore selected and combined to ensure all relevant manuscripts were identified, as follows: 'andrology', 'male infertility', 'erectile dysfunction, 'impotence,' 'penile deformity', 'penile curvature, 'peyronie's disease', 'priapism, 'penile fracture,' 'ejaculatory disorder, 'male sexual dysfunction, 'hypogonadism,' 'penile cancer,' 'squamous cell carcinoma' and 'penis'. Truncation using the asterisk function $\left(^{*}\right)$ was utilised for particular words with

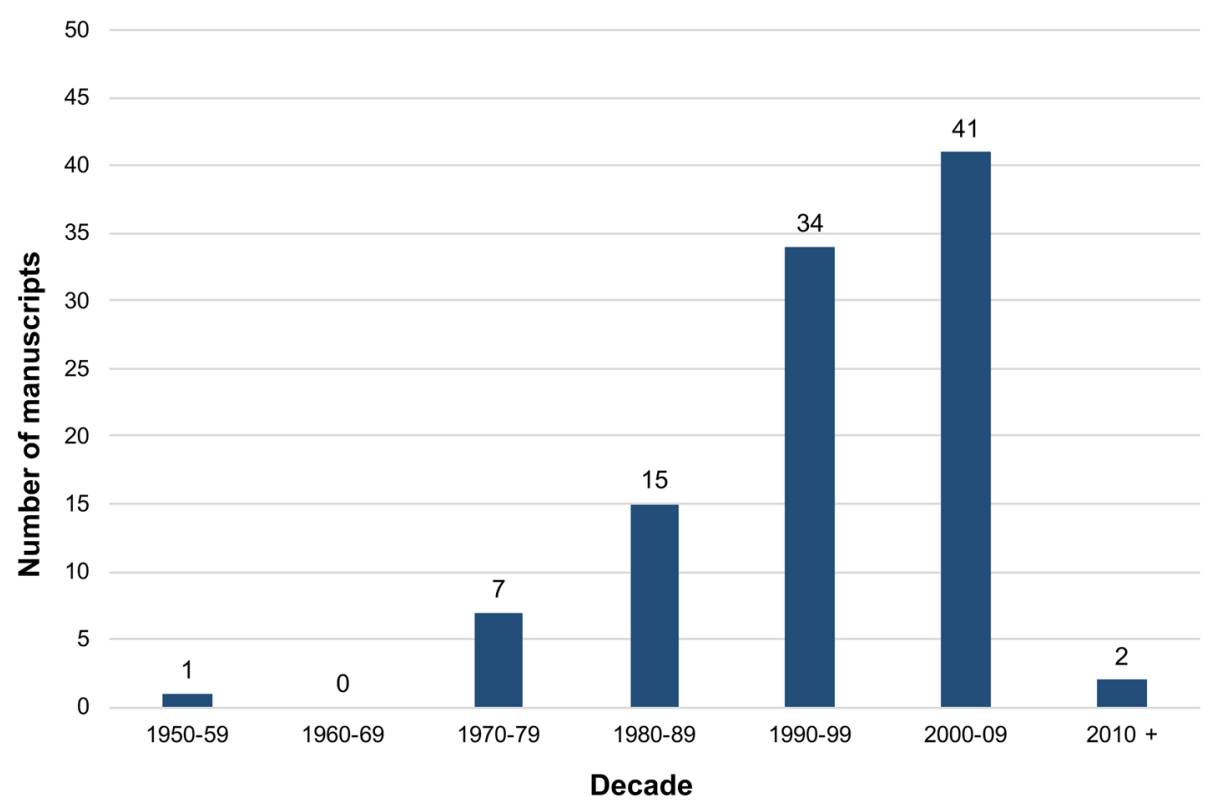

Fig. 1 Bar graph demonstrating the distribution of the 100 most cited articles according to the decade in which they were published 
Table 2 Journals in which the 100 most cited manuscripts were published, ranked according to number with corresponding impact factors at the time of review

\begin{tabular}{|c|c|c|c|}
\hline Journal Title & $\begin{array}{l}\text { Impact Factor } \\
\text { as of } 2016\end{array}$ & $\begin{array}{l}\text { Number of } \\
\text { Manuscripts } \\
\text { in Top } 100\end{array}$ & $\begin{array}{l}\text { Total number } \\
\text { of citations }\end{array}$ \\
\hline Journal of Urology & 5.157 & 11 & 6771 \\
\hline $\begin{array}{l}\text { New England Journal } \\
\text { of Medicine }\end{array}$ & 72.406 & 10 & 5388 \\
\hline $\begin{array}{l}\text { Journal of Clinical } \\
\text { Endocrinology and } \\
\text { Metabolism }\end{array}$ & 5.455 & 8 & 2610 \\
\hline $\begin{array}{l}\text { Journal of the American } \\
\text { Medical Association }\end{array}$ & 44.405 & 6 & 3074 \\
\hline Urology & 2.309 & 5 & 3784 \\
\hline Fertility and Sterility & 4.447 & 4 & 1171 \\
\hline $\begin{array}{l}\text { Proceedings of the National } \\
\text { Academy of Sciences of the } \\
\text { United States of America }\end{array}$ & 9.661 & 4 & 2127 \\
\hline European Urology & 16.265 & 3 & 1435 \\
\hline $\begin{array}{l}\text { Human Reproduction } \\
\text { Update }\end{array}$ & 11.748 & 3 & 1198 \\
\hline $\begin{array}{l}\text { International Journal of } \\
\text { Impotence Research }\end{array}$ & 1.293 & 3 & 2187 \\
\hline Journal of Andrology & 2.473 & 3 & 1142 \\
\hline Lancet & 47.831 & 3 & 993 \\
\hline Nature & 40.137 & 3 & 1264 \\
\hline Annals of Internal Medicine & 17.202 & 2 & 544 \\
\hline Endocrinology & 4.286 & 2 & 898 \\
\hline Human Reproduction & 5.02 & 2 & 515 \\
\hline $\begin{array}{l}\text { Journal of the National } \\
\text { Cancer Institute }\end{array}$ & 13.757 & 2 & 472 \\
\hline $\begin{array}{l}\text { American Journal of } \\
\text { Medicine }\end{array}$ & 5.55 & 1 & 276 \\
\hline $\begin{array}{l}\text { American Journal of } \\
\text { Reproductive Immunology }\end{array}$ & 3.013 & 1 & 299 \\
\hline Annals of Surgery & 8.98 & 1 & 269 \\
\hline $\begin{array}{l}\text { Bioorganic \& Medicinal } \\
\text { Chemistry Letters }\end{array}$ & 2.454 & 1 & 421 \\
\hline British Journal of Psychiatry & 6.347 & 1 & 374 \\
\hline British Journal of Urology ${ }^{a}$ & 1.69 & 1 & 423 \\
\hline $\begin{array}{l}\text { British Journal of Urology } \\
\text { International }\end{array}$ & 4.439 & 1 & 553 \\
\hline British Medical Journal & 17.215 & 1 & 421 \\
\hline $\begin{array}{l}\text { Current Medical Research } \\
\text { and Opinion }\end{array}$ & 2.757 & 1 & 297 \\
\hline Diabetes Care & 11.857 & 1 & 244 \\
\hline Diabetologia & 6.08 & 1 & 287 \\
\hline Endocrine Reviews & 15.745 & 1 & 233 \\
\hline $\begin{array}{l}\text { European Journal of } \\
\text { Endocrinology }\end{array}$ & 4.101 & 1 & 256 \\
\hline Experientia & 2.072 & 1 & 225 \\
\hline Heart & 6.059 & 1 & 270 \\
\hline
\end{tabular}

Table 2 Journals in which the 100 most cited manuscripts were published, ranked according to number with corresponding impact factors at the time of review (Continued)

\begin{tabular}{llll}
\hline $\begin{array}{l}\text { Journal Title } \\
\text { as of 2016 }\end{array}$ & $\begin{array}{l}\text { Impact Factor } \\
\text { Manuscripts } \\
\text { in Top 100 }\end{array}$ & $\begin{array}{l}\text { Total number } \\
\text { of citations }\end{array}$ \\
\hline $\begin{array}{l}\text { International Journal } \\
\text { of Cancer }\end{array}$ & 6.513 & 1 & 224 \\
$\begin{array}{l}\text { International Journal } \\
\text { of Clinical Practice }\end{array}$ & 2.14 & 1 & 331 \\
$\begin{array}{l}\text { Journal of the American } \\
\text { College of Cardiology }\end{array}$ & 19.896 & 1 & 253 \\
$\begin{array}{l}\text { Molecular Reproduction } \\
\text { and Development }\end{array}$ & 2.316 & 1 & 224 \\
$\begin{array}{l}\text { Nature Genetics } \\
\text { Nature Reviews Drug }\end{array}$ & 27.959 & 1 & 395 \\
$\begin{array}{l}\text { Discovery } \\
\text { Preventive Medicine }\end{array}$ & 57 & 1 & 240 \\
Psychosomatic Medicine & 3.434 & 1 & 431 \\
Radiology & 7.863 & 1 & 345 \\
Science & 37.296 & 1 & 298 \\
Urologic Clinics of & 2.22 & 1 & 492 \\
North America & & 1 & 225 \\
\hline Impact Factor atabe & & & \\
\hline
\end{tabular}

Impact Factor available for 2000 only

multiple relevant variations, for example the term 'peni"' was used to capture both 'penis' and 'penile'. These search terms were chosen to reflect the core topics published in the European Academy of Andrology-European Society of Andrological Urology Joint Educational Curriculum for Clinical Andrology Training in Europe [11].

The search was conducted on 5th June 2018 and included all manuscripts published in the English language from 1900 onwards. Results were subsequently ranked by citation number. Final interrogation of the database was independently performed by two assessors (NB and $\mathrm{TE})$. The 100 most cited articles were further evaluated according to subject, first and senior author, journal, year of publication, institution and country of origin. The 2016 impact factor of each journal was also identified from the Journal Citation Reports dataset [12]. In order to adjust for older articles accruing a higher number of citations over time the citation rate was calculated by dividing the number of citations by the number of years since publication. Articles were excluded if published prior to 1900, in languages other than English and/or if, after independent assessment by two researchers, it was agreed the main focus was not directly relevant to the field andrology. In cases of disagreement on the suitability for inclusion, the manuscript in question was discussed by both assessors and a consensus decision reached. 

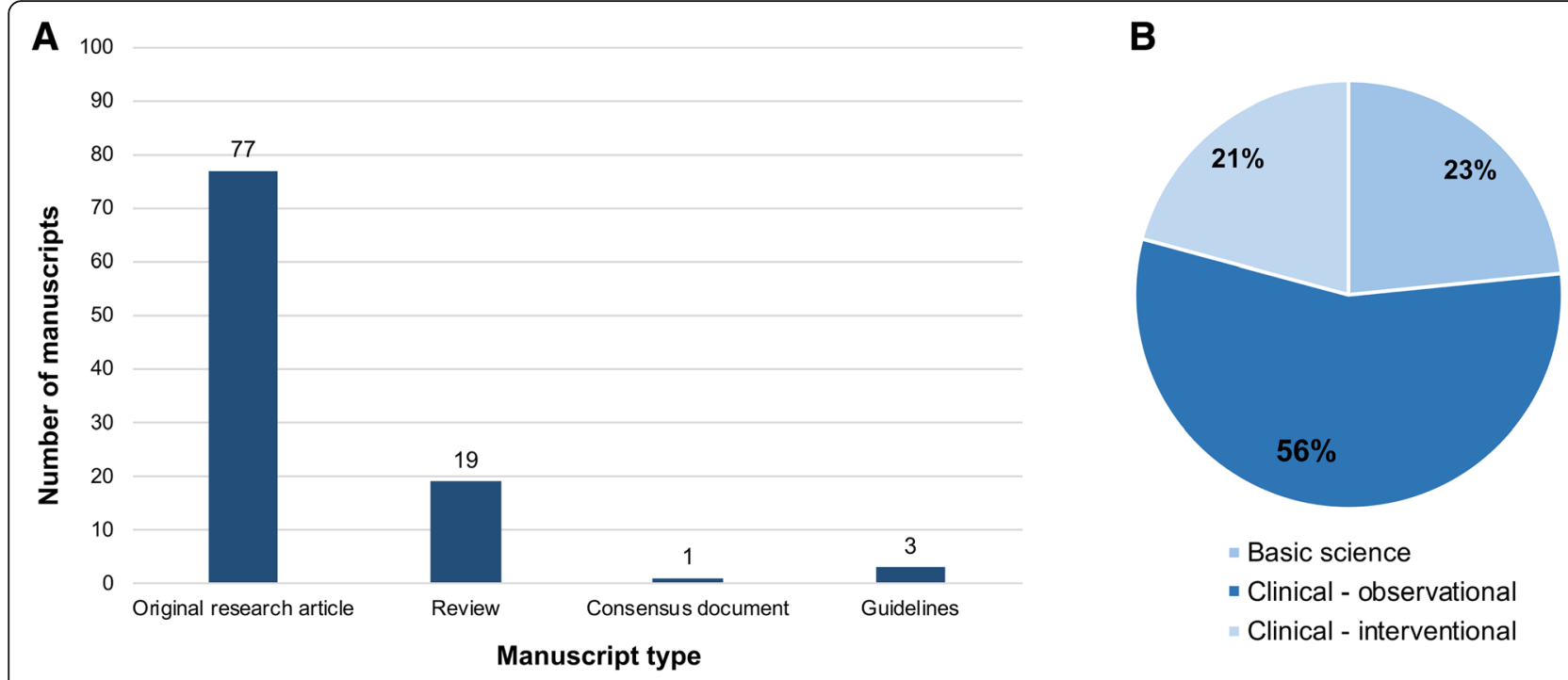

Fig. 2 Manuscript type. a Bar graph demonstrating composition of the 100 most cited articles according to manuscript type. b Pie chart demonstrating the study design of the 77 original research articles

\section{Results}

The Web of Science search returned a total of 24,128 manuscripts. Table 1 lists the 100 most cited articles as ranked by citation number, following application of exclusion criteria. Where two articles had equal numbers of citations, further stratification was based on citation rate. The most cited article was that by Feldman et al. describing the prevalence of and risk factors for erectile dysfunction (ED) in the Massachusetts Male Ageing Study, published in The Journal of Urology in 1994 and has been cited 2819 times [13].

The 100 most cited manuscripts were published over a broad time period, with the greatest proportion between 2000 and $2009(n=41)$, as demonstrated in Fig. 1. The most historic article was that by Macleod and Gold reporting comparative semen analysis in both 'fertile' and 'infertile' men, published in The Journal of Urology in 1951 and cited 239 times [14]. The most recent manuscript was that published in 2010 in European Urology by Hatzimouratidis, et al. outlining the European Association of Urology guidelines on investigation and management of male sexual dysfunction, which has been cited 420 times [15].

Table 2 outlines the 43 journals in which the top 100 manuscripts were published. The Journal of Urology (impact factor 5.157) published the highest number $(n=11)$, including the most cited article by Feldman et al. [13], and accrued a total overall citation number of 6771. This was followed by The New England Journal of Medicine, which published 10 manuscripts and was also the journal with the highest impact factor (72.406).
The country with the greatest number of publications was the United States of America $(n=66)$, followed by the United Kingdom $(n=12)$ and Canada $(n=5)$. The Massachusetts General Hospital was the institution with the greatest number of manuscripts $(n=7)$, followed jointly by the Cleveland Clinic and New England Research Institute ( $n=6$ respectively), all of which are based in the USA. RC Rosen [16-19] and TF Lue [20-22] were the first authors with the highest number of manuscripts in the top 100, achieving 4 and 3 respectively. A number of senior authors published more than one manuscript, with JB McKinlay achieving the greatest $(n=5)$, including the most cited article [13, 23-26].

Figure 2 gives the top 100 manuscripts according to type. The majority were original research articles $(n=$ 77, Fig. 2a), of which 59 (76.6\%) reported clinical outcomes (based on either observational or interventional methodology) and 18 (23.4\%) reported the findings of basic scientific work (Fig. 2b). The number of manuscripts pertaining to each of the main andrology themes are given in Fig. 3a. ED was the most common $(n=46)$, followed jointly by hypogonadism and male factor infertility $(n=24$ respectively). Figure $3 \mathrm{~b}$ demonstrates manuscript theme as strafitied by decade of publication. Hypogonadism was the most common theme prior to $1980(\mathrm{n}=4)$, after which ED remained the most common up until 2010. Despite an overall trend of increasing numbers of manuscripts focussing on ED within the top 100 during this period, the relative proportion of manuscripts fell with each decade $(66.7,47.1$ and $46.3 \%$ between 1980 and $89,1990-99$ and 2000-09 respectivelty). 


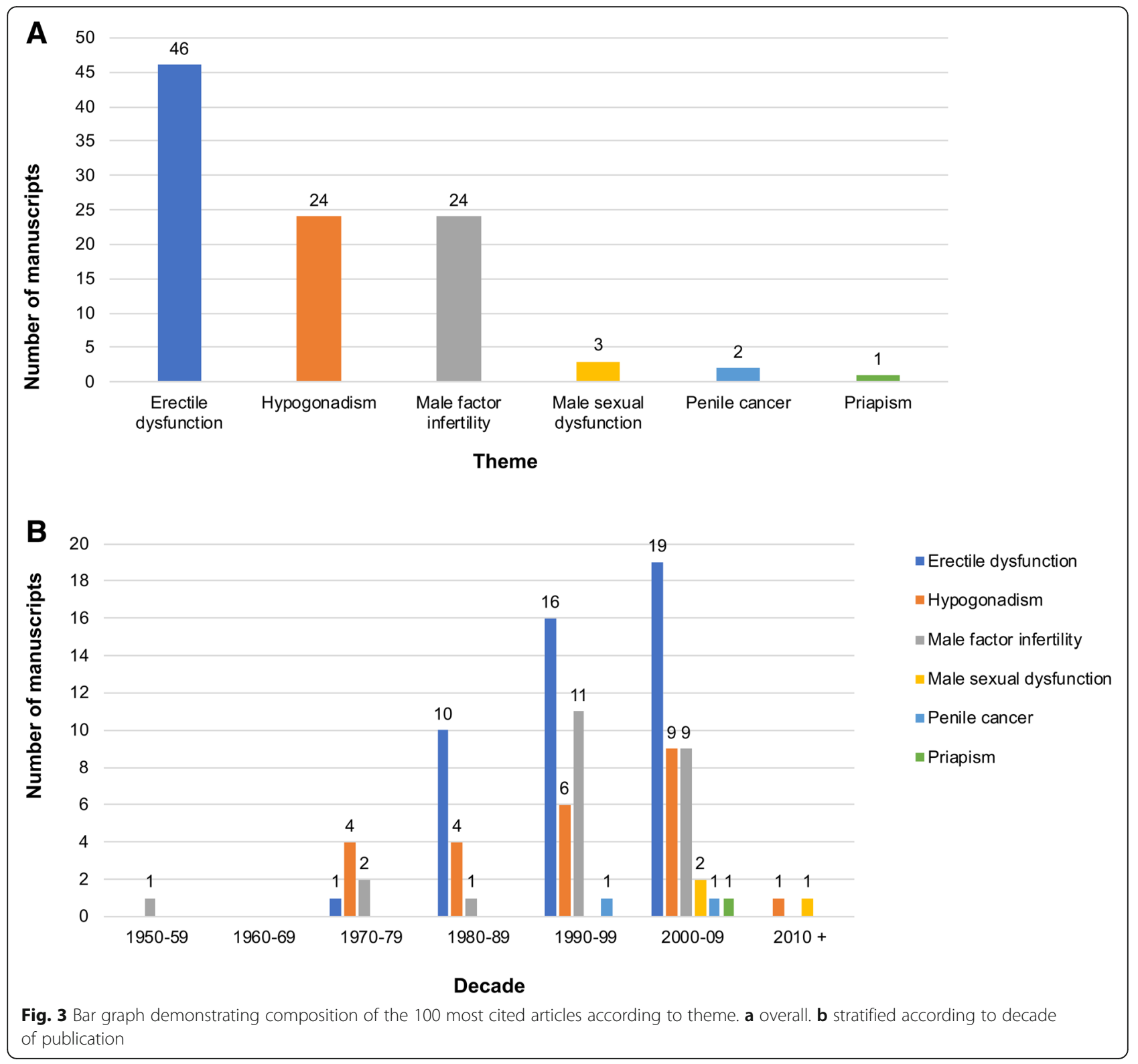

The citation rate of the top 10 manuscripts ranged from 118 to 45, as shown in Table 3. A number of articles from the top 10 remained the same when ranked by citation rate, although three were replaced by the more contemporary manuscripts by Wu, et al. $(2010,524$ citations) [27], Hatzimouratidis, et al. (2010, 420 citations) [15] and Tremellen (2008, 479 citations) [28].

\section{Discussion}

This study is the first bibliometric analysis to identify and analyse the most influential manuscripts in the field of andrology. A range of topics were represented within the top 100, which reflects the spectrum of clinical andrological practice as well as the variation in the specialist backgrounds of andrological practitioners and researchers. Similarly, there is significant overlap with other medical specialties including, but not limited to, endocrinology. Despite this overlap, the most prevalent theme of publication was the assessment and/or treatment of patients with ED, constituting 46 papers within the top 100. This included the most cited article by Feldman, et al. [13] describing the prevalence of, and risk factors for, ED in the Massachusetts Male Ageing Study, published in The Journal of Urology in 1994 and cited 2819 times. The Massachusetts Male Aging Study was a community-based, observational survey of non-institutionalised men between 40 and 70 years old conducted between 1987 to 1989 in cities and towns near Boston, Massachusetts. The aim was to correlate a self-administered erectile function questionnaire with an assessment of patients' overall health. The 
Table 3 Top 10 manuscripts with the highest citation rate

\begin{tabular}{|c|c|c|c|c|c|c|}
\hline Rank & Citation Rate & First Author & Senior Author & Title & First author institution & Country \\
\hline 1 & 118 & Rosen RC & Mishra A & $\begin{array}{l}\text { The international index of erectile function } \\
\text { (IIEF): A multidimensional scale for assessment } \\
\text { of erectile dysfunction }\end{array}$ & $\begin{array}{l}\text { University of Medicine and } \\
\text { Dentistry of New Jersey }\end{array}$ & USA \\
\hline 2 & 117 & Feldman HA & McKinlay JB & $\begin{array}{l}\text { Impotence and its medical and psychosocial } \\
\text { correlates - results of the Massachusetts male } \\
\text { aging study }\end{array}$ & New England Research Institute & USA \\
\hline 3 & 82 & de Roux N & Milgrom E & $\begin{array}{l}\text { Hypogonadotropic hypogonadism due to loss } \\
\text { of function of the KiSS1-derived peptide } \\
\text { receptor GPR54 }\end{array}$ & Hôpital de Bicêtre & France \\
\hline 4 & 76 & Goldstein I & Wicker PA & $\begin{array}{l}\text { Oral sildenafil in the treatment of erectile } \\
\text { dysfunction }\end{array}$ & Boston University Medical Centre & USA \\
\hline 5 & 70 & Rosen RC & Pena BM & $\begin{array}{l}\text { Development and evaluation of an abridged, } \\
\text { 5-item version of the International Index of } \\
\text { Erectile Function (IIEF-5) as a diagnostic tool } \\
\text { for erectile dysfunction }\end{array}$ & $\begin{array}{l}\text { Robert Wood Johnson Medical } \\
\text { School }\end{array}$ & USA \\
\hline 6 & 66 & Wu FCW & Huhtaniemi IT & $\begin{array}{l}\text { Identification of Late-Onset Hypogonadism in } \\
\text { Middle-Aged and Elderly Men }\end{array}$ & University of Manchester & UK \\
\hline 7 & 53 & Hatzimouratidis K & Wespes E & $\begin{array}{l}\text { Guidelines on Male Sexual Dysfunction: } \\
\text { Erectile Dysfunction and Premature Ejaculation }\end{array}$ & Aristotle University of Thessaloniki & Greece \\
\hline 8 & 51 & Droller MJ & Hall WH & $\begin{array}{l}\text { Impotence: NIH consensus development } \\
\text { panel on impotence }\end{array}$ & Mount Sinai Medical Center & USA \\
\hline 9 & 48 & Tremellen $\mathrm{K}$ & Tremellen $\mathrm{K}$ & $\begin{array}{l}\text { Oxidative stress and male infertility - a clinical } \\
\text { perspective }\end{array}$ & $\begin{array}{l}\text { Repromed \& University of } \\
\text { Adelaide }\end{array}$ & Australia \\
\hline 10 & 45 & Rosen RC & Giuliano F & $\begin{array}{l}\text { Lower urinary tract symptoms and male } \\
\text { sexual dysfunction: The multinational survey } \\
\text { of the aging male (MSAM-7) }\end{array}$ & $\begin{array}{l}\text { Robert Wood Johnson Medical } \\
\text { School }\end{array}$ & USA \\
\hline
\end{tabular}

authors noted a strong correlation with patients who had vascular, cardiac or smoking-related diseases and concluded that ED was associated with potentially reversible age-related changes.

The self-administered erectile function questionnaire reported in the Feldman, et al. study differed from the now more commonly used International Index of Erectile Function (IIEF), which was first described three years later in 1997 by Rosen, et al. [16]. This landmark publication constituted the second most cited article in this bibliometric analysis. Similarly, the fourth most cited article described an updated version of the IIEF questionnaire and was again published by Rosen, et al. [17]. The reason that these papers have been cited so frequently is most likely due to both the high overall prevalence of publications focussing on ED, and the fact that the IIEF-5 is widely used in clinical practice to measure the severity of ED and is hence frequently used in research studies as an 'objective' measurement of function, treatment efficacy or response.

Fourteen manuscripts in the top 100 focussed specifically on the treatment of ED. These ranged in age from the article by Brindley in 1983 examining the effects of intra-cavernosal alpha-blockade [29], to that by McVary, et al. in 2007 reporting the results of a randomised controlled trial investigating the effects of oral sildenafil on both ED and urinary symptoms [30]. This analysis demonstrates that there was a significant increase in the number of influential manuscripts focussing on the treatment of ED following publication of the landmark paper by Goldstein, et al. in 1998 reporting the effectiveness of oral sildenafil [31]. This was the first paper to describe an oral treatment for ED and is the third most cited manuscript in the top 100. Prior to this time, treatments had been relatively intolerable for patients, including vacuum tumescence devices, intracavernosal injections of vasoactive agents, transurethral delivery of alprostadil, and invasive surgical procedures. The availability of oral treatments for ED subsequently resulted in a rapid increase in research being undertaken into all aspects of the condition, which is reflected in the numerous manuscripts published after 1998 that feature in the top 100 (Figs. 1 and 3b). Furthermore, it is probable that there was an increase in self-reporting of ED and a drive towards increased research funding and activity when a number of 'tolerable' treatments became available.

A significant majority of manuscripts were published by authors in the United States of America $(n=66)$, followed by the United Kingdom $(n=12)$ and Canada $(n=5)$. This disparity between the USA and other countries may reflect the subspecialisation that occurs in contemporary American Urological practice compared with other geographical regions [32]. This means that clinicians are more likely to be solely practicing andrology, 
with less emphasis on provision of 'core urological' services, therefore potentially allowing more time for academic pursuits. This geographical dominance has also been observed in other bibliometric analyses [7] and may also be explained by differences in academic focus in relation to clinical practice, with more funding provided to clinicians' academic work in the USA compared to elsewhere, which in turn appears to correlate with a higher quality of research [33].

It is important to note that only two manuscripts within the top 100 focus on the management of penile cancer (Maden, ranked 79 [34] and Daling, ranked 98 [35]). This is the only cancer that is commonly managed by andrologists and therefore one would expect to see a greater number of manuscripts related to its pathophysiology, treatment and follow-up within the top 100 . However, it is likely that the low incidence of this condition makes it a relative 'Cinderella' subspecialty within the field and therefore papers focussed on penile cancer are less widely cited when compared to the much more commonly encountered conditions of ED and hypogonadism [36]. Moreover, due to the paucity of cases seen in routine practice it is difficult to establish a cohort of sufficient size for high quality observational or interventional research. This, coupled with the known difficulties in conducting high quality surgical trials [37], means that manuscripts are often of low levels of evidence, thus precluding them from publication in high impact factor journals.

The journals in which the top 100 manuscripts were published varied significantly both in theme and impact factor. The latter was particularly varied and ranged from 72.406 to 1.293 (median 5.5025). Interestingly, impact factor did not necessarily correlate with the most cited papers. For example, the second most cited paper by Rosen, et al. [16] was published in 'Urology', which was the sixth-lowest ranked journal in terms of impact factor within this analysis (2.309). One explanation for this variation is the multidisciplinary nature of many conditions encountered under the umbrella of andrology. Furthermore, the subspecialised nature of many andrological conditions means that manuscripts pertaining to these topics are often not directly relevant to 'core' clinical practice and are therefore less likely to be published in higher impact factor journals that seek to meet the interests of a broad audience.

The main limitation of bibliometric analysis is the potential for a number of types of bias. Firstly, disproportionate citation may result from institutional bias, language biases, self-citation or powerful person bias. In addition, older manuscripts may receive more citations due to the length of time in which they are in the public domain. Although the use of citation rate attempts to control for this, it may take a number of years for influential manuscripts to accrue citations due to the publication lead-time for their citing manuscript. A further limitation is the inclusion of only first and senior authors, and the institution of the first author. It is possible that several first authors will have co-authored other papers in the top 100 and therefore be underrepresented in the current study. Finally, searching based on title means a small number of manuscripts that have key andrological themes without pertaining to these in their title may not have been identified.

\section{Conclusion}

This list of highly cited papers identifies the topics and authors that have made the most impact in the discipline of andrology over the last century. There is a clear predominance of manuscripts focusing on the treatment and pathophysiology of ED, which should therefore be considered the most widely researched, published and cited field within andrological practice. This study provides a reference of what may be considered as the most influential papers in andrology and serves as a inidcation of what comprises a 'highly citable' manuscript for both researchers and clinicians.

\section{Abbreviations \\ ED: Erectile dysfunction; IIEF: International Index of Erectile Function; USA: United States of America}

\section{Acknowledgements}

Not applicable.

\section{Funding}

This research did not receive any specific grant from funding agencies in the public, commercial, or not-for-profit sectors.

Availability of data and materials

All relevant data included in this manuscript.

\section{Authors' contributions}

$N B, T E, A B, M S$ and $G B$ were responsible for study initiative and design. NB and TE undertook data collection and analysis. All authors were involved in interpretation of data, drafting and revision of the manuscript and provided approval of the final version for publication.

Ethics approval and consent to participate Not applicable.

\section{Consent for publication}

Not applicable.

\section{Competing interests}

The authors declare that they have no competing interests.

\section{Publisher's Note}

Springer Nature remains neutral with regard to jurisdictional claims in published maps and institutional affiliations.

\section{Author details}

${ }^{1}$ Division of Cancer and Genetics, Cardiff University School of Medicine, Heath Park, Cardiff CF14 4XN, UK. '2Department of Urology, Cwm Taf 
University Health Board, Royal Glamorgan Hospital, Llantrisant CF72 8XR, UK ${ }^{3}$ Faculty of Life Sciences and Education, University of South Wales, Pontypridd CF37 4BD, UK.

Received: 10 September 2018 Accepted: 6 November 2018 Published online: 12 December 2018

\section{References}

1. Isidori A. The history of modern andrology. Med Secoli. 2001;13(2):255-68.

2. Murray MR, Wang T, Schroeder GD, Hsu WK. The 100 most cited spine articles. Eur. Spine J. 2012;21(10):2059-69.

3. Paladugu R, Schein M, Gardezi S, Wise L. One hundred citation classics in general surgical journals. World J Surg. 2002;26(9):1099-105.

4. Loonen MP, Hage JJ, Kon M. Plastic surgery classics: characteristics of 50 top-cited articles in four plastic surgery journals since 1946. Plast Reconstr Surg. 2008;121(5):320-7.

5. Kelly J, Glynn R, O'Briain D, Felle P, McCabe J. The 100 classic papers of orthopaedic surgery a bibliometric analysis. J Bone Joint Surg Br. 2010; 92(10):1338-43.

6. Ellul T, Bullock N, Abdelrahman T, Powell AG, Witherspoon J, Lewis WG. The 100 most cited manuscripts in emergency abdominal surgery: a bibliometric analysis. Int J Surg. 2017;37:29-35.

7. Mellor KL, Powell AG, Lewis WG. Laparoscopic surgery's 100 most influential manuscripts: a bibliometric analysis. Surg Laparosc Endosc Percutan Tech. 2018;28(1):13-9

8. Hennessey K, Afshar K, MacNeily AE. The top 100 cited articles in urology. Can Urol Assoc J. 2009;3(4):293-302

9. Nason GJ, Tareen F, Mortell A. The top 100 cited articles in urology: an update. Can Urol Assoc J. 2013;7(1-2):16-24.

10. Zhang Y, Xiao F, Lu S, Song J, Zhang C, Li J, et al. Research trends and perspectives of male infertility: a bibliometric analysis of 20 years of scientific literature. Andrology. 2016;4(6):990-1001.

11. European Academy of Andrology-European Society of Andrological Urology. Joint educational curriculum for clinical andrology training in Europe: the sub-speciality in andrology. Munster, Germany: European academy of Andrology; 2008.

12. Clarivate Analytics. 2016 journal impact factor. Journal citation reports, Clarivate Analytics; 2017

13. Feldman HA, Goldstein I, Hatzichristou DG, Krane RJ, McKinlay JB. Impotence and its medical and psychosocial correlates - results of the Massachusetts male aging study. J Urol. 1994;151(1):54-61.

14. Macleod J, Gold RZ. The male factor in fertility and infertility .II. Spermatozoon counts in 1000 men of known fertility and in 1000 cases of infertile marriage. J Urol. 1951;66(3):436-49.

15. Hatzimouratidis K, Amar E, Eardley I, Giuliano F, Hatzichristou D, Montorsi F, et al. Guidelines on male sexual dysfunction: erectile dysfunction and premature ejaculation. Eur Urol. 2010;57(5):804-14.

16. Rosen RC, Riley A, Wagner G, Osterloh $\mid H$, Kirkpatrick J, Mishra A. The international index of erectile function (IIEF): a multidimensional scale for assessment of erectile dysfunction. Urology. 1997;49(6):822-30.

17. Rosen RC, Cappelleri JC, Smith MD, Lipsky J, Pena BM. Development and evaluation of an abridged, 5 -item version of the international index of erectile function (IIEF-5) as a diagnostic tool for erectile dysfunction. Int Impot Res. 1999;11(6):319-26.

18. Rosen R, Altwein J, Boyle P, Kirby RS, Lukacs B, Meuleman E, et al. Lower urinary tract symptoms and male sexual dysfunction: the multinational survey of the aging male (msam-7). Eur Urol. 2003:44(6):637-49.

19. Rosen RC, Fisher WA, Eardley I, Niederberger C, Nadel A, Sand M. The multinational men's attitudes to life events and sexuality (males) study: I. prevalence of erectile dysfunction and related health concerns in the general population. Curr Med Res Opin. 2004;20(5):607-17.

20. Lue TF. Drug therapy: erectile dysfunction. N Engl J Med. 2000;342(24):1802-13.

21. Lue TF, Tanagho EA. Physiology of erection and pharmacological management of impotence. J Urol. 1987;137(5):829-36.

22. Lue TF, Hricak H, Marich KW, Tanagho EA. Vasculogenic impotence evaluated by high-resolution ultrasonography and pulsed doppler spectrum analysis. Radiology. 1985;155(3):777-81.

23. Johannes $C B$, Araujo AB, Feldman HA, Derby CA, Kleinman KP, McKinlay $\mathrm{JB}$. Incidence of erectile dysfunction in men 40 to 69 years old: longitudinal results from the Massachusetts male aging study. J Urol. 2000;163(2):460-3.
24. Feldman HA, Johannes CB, Derby CA, Kleinman IC, Mohr BA, Araujo AB, et al. Erectile dysfunction and coronary risk factors: prospective results from the Massachusetts male aging study. Prev Med. 2000;30(4):328-38.

25. Araujo AB, Durante R, Feldman HA, Goldstein I, McKinlay JB. The relationship between depressive symptoms and male erectile dysfunction: crosssectional results from the Massachusetts male aging study. Psychosom Med. 1998:60(4):458-65

26. Derby CA, Mohr BA, Goldstein I, Feldman HA, Johannes CB, McKinlay JB. Modifiable risk factors and erectile dysfunction: can lifestyle changes modify risk? Urology. 2000;56(2):302-6.

27. Wu FCW, Tajar A, Beynon JM, Pye SR, Silman AJ, Finn JD, et al. Identification of late-onset hypogonadism in middle-aged and elderly men. N Engl J Med. 2010:363(2):123-35.

28. Tremellen K. Oxidative stress and male infertility - a clinical perspective. Hum Reprod Update. 2008;14(3):243-58.

29. Brindley GS. Cavernosal alpha-blockade - a new technique for investigating and treating erectile impotence. Br J Psychiatry. 1983:143:332-7.

30. McVary KT, Monnig W, Camps JL, Young JM, Tseng $L$, van den Ende G. Sildenafil citrate improves erectile function and urinary symptoms in men with erectile dysfunction and lower urinary tract symptoms associated with benign prostatic hyperplasia: a randomized, double-blind trial. J Urol. 2007; 177(3):1071-7.

31. Goldstein I, Lue TF, Padma-Nathan H, Rosen RC, Steers WD, Wicker PA, et al. Oral sildenafil in the treatment of erectile dysfunction. N Engl J Med. 1998; 338(20):1397-404

32. Gee WF, Holtgrewe HL, Albertsen PC, Cooper TP, Fenninger RB, Litwin MS, et al. Subspecialization, recruitment and retirement trends of american urologists. J Urol. 1998;159(2):509-11.

33. Reed DA, Cook DA, Beckman TJ, Levine RB, Kern DE, Wright SM. Association between funding and quality of published medical education research. JAMA. 2007;298(9):1002-9.

34. Maden C, Sherman KJ, Beckmann AM, Hislop TG, Teh CZ, Ashley RL, et al. History of circumcision, medical conditions, and sexual-activity and risk of penile cancer. J Natl Cancer Inst. 1993;85(1):19-24.

35. Daling JR, Madeleine MM, Johnson LG, Schwartz SM, Shera KA, Wurscher MA et al. Penile cancer: importance of circumcision, human papillomavirus and smoking in in situ and invasive disease. Int J Cancer. 2005;116(4):606-16.

36. Pow-Sang MR, Ferreira U, Pow-Sang JM, Nardi AC, Destefano V. Epidemiology and natural history of penile cancer. Urology. 2010;76(2):S2-6.

37. Cook JA. The challenges faced in the design, conduct and analysis of surgical randomised controlled trials. Trials. 2009;10(1):9.

\section{Ready to submit your research? Choose BMC and benefit from:}

- fast, convenient online submission

- thorough peer review by experienced researchers in your field

- rapid publication on acceptance

- support for research data, including large and complex data types

- gold Open Access which fosters wider collaboration and increased citations

- maximum visibility for your research: over $100 \mathrm{M}$ website views per year

At BMC, research is always in progress.

Learn more biomedcentral.com/submissions 